\title{
Alcohol control and the COVID-19 crisis on the other side of the Atlantic
}

\author{
Alain Braillon ${ }^{1}$ \\ Received: 6 August 2020 / Accepted: 18 August 2020 / Published online: 2 September 2020 \\ (C) The Canadian Public Health Association 2020
}

\section{Dear Editor:}

Lange et al. (2020) rightly questioned the lack of restrictions on the availability of alcoholic beverages in Canada during the COVID-19 crisis. Indeed, the poor management of the crisis exacerbated risk factors for initiation, worsening and relapse of alcohol use, as well as other addictive substances, at a period with even poorer access to treatments. In contrast, South Africa totally banned alcohol sales and saw a reported decrease of over $80 \%$ in the number of violent incidents (see Lange et al. 2020).

France was among those countries choosing severe lockdown, and the minister of health issued a decree on 14 March 2020 with a positive list of essential activities and businesses where liquor shops ranked just after bread and pastry shops (Véran 2020a). On March 18, he added tobacco shops and e-cigarette shops, ranking them just after "food retail trade on stalls and markets" (Véran 2020b). The latter were forbidden on March 23 by the Prime Minister.

France's public policy is not only comprehensive but longterm-oriented:

a) For alcohol, the new prime minister announced on August 5 a new financial envelope of $€ 80$ million to support the wine industry, in addition to initial aid of $€ 170$ million announced in May (Pallier 2020). Coincidentally, the wine industry is one of the very few exporting industries to generate a trade surplus.

b) For tobacco, on April 23, the Ministry of Health suspended online sales of nicotine replacement therapy and restricted delivery by pharmacies to one month's therapy (Véran 2020c), and the European ban on menthol cigarettes to be enforced on May 20 was postponed to

Alain Braillon

1 Amiens, France
July 31 . In France, daily smoking prevalence was $24 \%$ in 2019, without significant changes from 2018. Coincidentally, revenue from tobacco taxes is equivalent to one fourth of the revenue from the income tax.

As a skeptic, I do not believe in coincidences.

\section{Compliance with ethical standards}

Conflict of interest As a member of the High Council of Public Health, the expert body of the Ministry of Health for the French government, AB had to sign a form about the "duty of confidentiality". In France, there is no Public Servants Disclosure Protection Act as in Canada, and the Criminal Code is specifically designed to sue civil servants for breaches of their "duty of confidentiality" (Law 83-634, Article 26).

The editor of "La Revue du vin de France", the benchmark wine magazine since 1927 , claimed $(06 / 21 / / 2017) \mathrm{AB}$ is a member of the hygienist lobby (http://www.larvf.com/vin-cote-rotie-contre-lexomilaudrey-bourolleau,4540951.asp).

\section{References}

Lange, S., Probst, C, Rehm, J. (2020). Coronavirus disease 2019 crisis and intentional injuries: now is not the time to erode alcohol control policies. Can J Public Health. Online Aug 5. doi:10.17269/s41997020-00391-6.

Pallier, Z. (2020). The government is stepping up its aid to the wine industry. La Croix 5 August. Available at https://wwwlacroixcom/Economie/Le-gouvernement-renforce-aide-filiereviticole-2020-08-05-1201107902. Accessed 6 August 2020.

Véran, O. (2020a). [Decree of March 14, 2020 laying down various measures relating to the fight against the spread of the Covid-19 virus.] JORF n ${ }^{\circ} 0064$. NOR: SSAS2007753A. Available at https:// www.legifrance.gouv.fr/affich Texte.do?cidTexte= JORFTEXT000041723302\&categorieLien=id. 6 August 2020.

Véran, O. (2020b). [Decree of March 17, 2020 supplementing the order of March 14, 2020 carrying various measures relating to the fight against the spread of the covid-19 virus.] JORF n ${ }^{\circ} 0067$. NOR: SSAZ2007919A. Available at https://www.legifrance.gouv.fr/ affichTexte.do?cidTexte=JORFTEXT000041731893\&categorieLien= id. Accessed 6 August 2020. 
Véran, O. (2020c). [Decree of April 23, 2020 supplementing the order of March 23, 2020 prescribing the measures for the organization and functioning of the health system necessary to deal with the epidemic of Covid19 in the context of the state of health emergency.] JORF. n 0100 . NOR: SSAZ2010368A. Available at https://www.legifrance.gouv.fr/
affichTexte.do?cidTexte=JORFTEXT000041817219\&categorieLien=id. Accessed 5 July 2020.

Publisher's note Springer Nature remains neutral with regard to jurisdictional claims in published maps and institutional affiliations. 